\title{
Amiodarone and its Pulmonal Toxicity
}

\author{
Kemalasari Nas Darisan, ${ }^{*}$ Jamal Zaini, ${ }^{*}$ Yoga Yuniadi ^
}

*Department of Pulmonology, Faculty of Medicine, University of Indonesia

^ Department of Cardiology and Vascular Medicine, Faculty of Medicine, University of Indonesia, and National Cardiovascular Center Harapan Kita, Jakarta
Amiodarone is an antiarrhythmic agent commonly used to treat supraventricular and ventricular arrhythmias. The drug prevents the recurrence of life-threatening ventricular arrhythmias and produces a modest reduction of sudden deaths in high-risk patients. This drug is an iodine-containing compound that tends to accumulate in several organs, including the lungs. It has been associated with a variety of adverse events. Of these events, the most serious is amiodarone pulmonary toxicity. Although the incidence of this complication has decreased with the use of lower doses of amiodarone, it can occur with any dose. Because amiodarone is widely used, all clinicians should be vigilant of this possibility. Pulmonary toxicity usually manifests as an acute or subacute pneumonitis, typically with diffuse infiltrates on chest x-ray and high-resolution computed tomography. Other, more localized, forms of pulmonary toxicity may occur, including pleural disease, migratory infiltrates, and single or multiple nodules. With early detection, the prognosis is good. Most patients diagnosed promptly respond well to the withdrawal of amiodarone and the administration of corticosteroids, which are usually given for four to 12 months. It is important that physicians be familiar with amiodarone treatment guidelines and follow published recommendations for the monitoring of pulmonary as well as extrapulmonary adverse effects.

(J Kardiol Indones. 2013;34: I 13-25)

Keywords: Amiodarone, lung toxicity, Drug toxicity 
Jurnal

Kardiologi Indonesia

J Kardiol Indones. 2013;34:113-25

ISSN $0126 / 3773$

\title{
Amiodaron dan Toksisitas terhadap Paru
}

\author{
Kemalasari Nas Darisan, ${ }^{*}$ Jamal Zaini, ${ }^{*}$ Yoga Yuniadi ^
}

\begin{abstract}
Amiodaron merupakan obat antiaritmia yang umumnya digunakan untuk aritmia supraventrikular dan aritmia ventrikel. Obat ini mencegah aritmia ventrikel berulang yang mengancam nyawa dan menurunkan kematian mendadak pada pasien berisiko tinggi. Obat ini mengandung senyawa yodium yang cenderung menumpuk di beberapa organ termasuk paru. Hal inilah yang dikaitkan menimbulkan berbagai efek samping amiodaron. Peristiwa yang paling serius adalah toksisitas amiodaron terhadap paru. Meskipun kejadian komplikasi ini mengalami penurunan dengan penggunaan amiodaron dosis yang lebih rendah dari biasanya namun hal ini masih dapat terjadi pada dosis berapapun. Oleh karena itu semua dokter harus waspada terhadap kemungkinan ini. Manifestasi toksisitas paru biasanya berupa pneumonitis akut atau subakut yang ditandai infiltrat difus pada foto toraks dan High Resolution Computed Tomography (HRCT). Toksisitas paru akibat amiodaron dapat terjadi secara lokal seperti pleura, berupa infiltrat, nodul tunggal atau ganda. Prognosis semakin baik dengan deteksi dini. Sebagian besar pasien dengan efek samping amiodaron yang terdiagnosis dini berespon baik dengan pemberian kortikosteroid yang dapat diberikan selama empat sampai 12 bulan. Penting bagi dokter yang sering menggunakan obat amiodaron untuk mengikuti aturan yang direkomendasikan dan juga melakukan pemantauan terhadap paru serta efek sampingnya.
\end{abstract}

(J Kardiol Indones. 2013;34:113-25)

Kata kunci: Amiodaron, toksisitas paru, toksisitas obat

\section{Pendahuluan}

A miodaron merupakan salah satu obat antiaritmia yang paling sering diresepkan di Amerika Utara. Obat ini telah diresepkan sekitar 500.000 di Kanada pada tahun 2007. Peresepan obat ini telah meningkat selama tiga tahun terakhir dibandingkan sotalol yang sedikit

\section{Alamat Korespondensi:}

dr. Kemalasari Nas Darisan. Departemen Pulmonologi dan Kedokteran Respirasi. RS Persahabatan, Jakarta. E-mail: drkemalasari@ gmail.com mengalami penurunan. Negara lain seperti Australia penggunaannya meningkat sekitar empat kali lipat pada tahun 1994-2003.

Popularitas amiodaron dapat dijelaskan oleh karena keberhasilan dan kegunaannya dalam mengurangi atau mencegah aritmia secara umum. Amiodaron awalnya dikembangkan sebagai agen antiangina karena bersifat vasodilator, belakangan ditemukan untuk menekan takiaritmia. Hal ini dikarenakan amiodaron memiliki efek biokimia dan elektrofisiologi yang baik. ${ }^{1,3,4}$ Secara klinis amiodaron telah digunakan dalam pengobatan aritmia ventrikel seperti ventrikel takikardi berulang dan ventrikel fibrilasi. Amiodaron dalam situasi akut 
dapat diberikan secara intravena dengan onset cepat untuk tindakan yang sangat penting. ${ }^{\text {, }}$

Namun demikian ditemukan pula berbagai efek samping akibat amiodaron. Toksisitas paru akibat amiodaron (TPA) merupakan toksisitas yang paling serius ditemukan diantara berbagai efek sampingnya. Peningkatan pemakaian amiodaron dihadapkan pada efek samping seperti pneumonitis dan fibrosis paru. Kejadian awal TPA dilaporkan 2-17\%. Insiden menurun pada pasien yang diberikan amiodaron kurang dari $300 \mathrm{mg}$. Angka mortalitas meningkat bila kelainan berkembang menjadi sindrom pernapasan akut sebesar $1 \%{ }^{4}$

Tinjauan pustaka ini akan membahas mengenai penggunaan klinis dan farmakologi amiodaron secara ringkas terutama mengenai kejadian, gambaran klinis, pemeriksaan penunjang dan pengobatan TPA. Hal ini diharapkan berguna sebagai rekomendasi untuk memantau pasien yang menggunakan amiodaron.

\section{Farmakologi Klinik}

\section{Farmakokinetik}

Amiodaron merupakan senyawa yodium yang mengandung beberapa kesamaan struktural dengan tiroksin. Amiodaron dapat menyebabkan hipo maupun hipertiroidisme akibat kandungan yodiumnya. Inhibisi tiroksin deiodinasi ke triiodotiroksin telah berkontribusi untuk keberhasilan antiaritmia. ${ }^{4}$

Hal terpenting yang perlu diketahui adalah bahwa amiodaron memiliki sifat kelarutan lemak yang tinggi (lipofilik). Amiodaron cenderung menumpuk secara luas pada jaringan adiposa dan organ perfusi lainnya seperti hati, paru dan limpa. ${ }^{1,4,5}$ Absorpsi amiodaron dengan pemberian oral di sistem pencernaan manusia berjalan lambat dan tidak sempurna (35-65\%), meskipun bioavailabilitasnya meningkat bila diberikan bersama makanan. ${ }^{3}$ Jus anggur dapat menghambat metebolisme amiodaron sehingga dapat meningkatkan kadar obat. ${ }^{4}$ Konsentrasi serum paling sedikit antara 1-2 mikrogram/mL untuk mendapatkan efek terapi. Kadar serum tertinggi dicapai setelah pemakaian oral selama 4-7 jam. ${ }^{3}$ Onset kerja sesudah pemberian oral agak terhambat dan kadar terapeutik amiodaron yang stabil baru dapat dicapai setelah beberapa bulan, kecuali bila diberikan dosis loading sebelumnya. ${ }^{3}$

Deiodinasi merupakan salah satu mekanisme bersihan amiodaron. Amiodaron akan mengalami jalur eliminasi utama melalui metabolisme di hati oleh enzim sitokrom P450 menjadi metabolit utamanya yaitu desethylamiodaron (DEA) yang memiliki efek antiaritmia sebanding dengan obat induknya. Hal ini ditunjukkan dalam gambar 1 . Waktu paruh amiodaron juga sangat bervariasi dan panjang yang berkisar antara 16-180 hari (rata-rata 52 hari). Hal ini disebabkan penyimpanan dan daya ikat yang kuat pada jaringan adiposa. Amiodaron akan diekskresikan melalui sistem bilier dan sejumlah kecil amiodaron dan DEA dapat ditemukan dalam urin. ${ }^{6-9}$
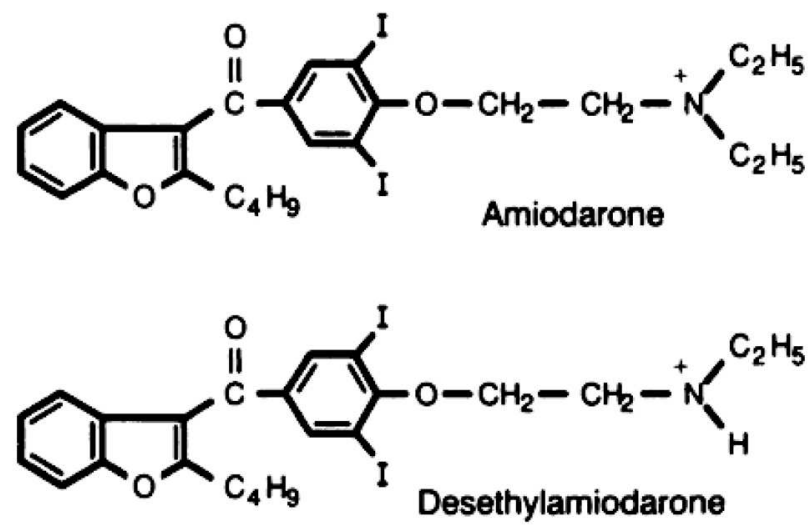

Gambar 1. Struktur molekul amiodaron dan metabolit primernya yaitu desethylamiodaron.

Dikutip dari (9)

\section{Efek elektrofisiologi}

Amiodaron merupakan terutama obat antiaritmia kelas III (berdasarkan klasifikasi Vaughan Williams) yang secara elektrofisiologi berefek memperpanjang interval QT. Efek lain obat ini : memperlambat frekuensi jantung dan memperlambat konduksi nodul atrioventrikular (melalui blokade saluran kalsium dan reseptor $\beta$ ), memperpanjang waktu refrakter (melalui blokade saluran kalium dan natrium), dan memperlambat konduksi intrakardia (melalui blokade saluran natrium).

\section{Indikasi}

\section{Pengobatan jangka panjang}

Amiodaron telah terbukti sebagai obat pencegahan sekunder aritmia ventrikel dan mengancam jiwa. The North American Society for Pacing and Electrophysiology 
(NASPE) merekomendasikan amiodaron sebagai agen antiaritmia pilihan pada takiaritmia ventrikel berkelanjutan terutama dengan disfungsi ventrikel kiri. ${ }^{4}$

Studi penggunaan amiodaron terutama untuk mencegah kematian mendadak pada pasien risiko tinggi memiliki hasil yang beragam. Satu dari 13 studi meta-analisis pada pasien dengan gagal jantung kongestif atau infark miokard menunjukkan penurunan kecil pada angka mortalitas tahunan total yaitu dari 12,3\% menjadi 10,9\% (dengan absolute risk reduction (ARR) 2,4 dan number needed to treat (NTT) 42). ${ }^{5}$ Manfaat terapi amiodaron lebih jelas pada pasien gagal jantung kongestif karena terbukti menurunkan angka mortalitas dari 24,3\% menjadi 19,9\% pertahun (ARR, 4,4\%; NNT, 23) (metaanalisis berbukti A). Pengobatan primer yaitu dengan implantable cardioverter defibrillators (ICDs) lebih efektif daripada amiodaron untuk menurunkan angka mortalitas pada pasien risiko tinggi dengan infark miokard sebelumnya (meta- analisis berbukti A) ${ }^{6-7}$ Amiodaron dapat digunakan sebagai terapi tambahan untuk menurunkan frekuensi penggunaan defibrilator berulang dalam mengendalikan fibrilasi atrium untuk pasien tertentu. Efikasi relatif amiodaron dan ICD dalam mencegah kematian mendadak pada pasien tanpa penyakit koroner masih diselidiki. ${ }^{4}$

Amiodaron sering digunakan dalam pengobatan fibrilasi atrium meskipun badan pengawas obat dan makanan di Amerika belum menyetujui indikasi ini. Berbagai protokol merekomendasikan amiodaron sebagai obat lini kedua untuk terapi jangka panjang fibrilasi atrium yang disertai kelainan struktur jantung dan pada pasien yang memiliki keluhan simtomatik tanpa kelainan jantung. Beberapa studi kecil telah menunjukkan bahwa amiodaron mirip dengan quinidin dan sotalol pada pasien fibrilasi atrium. Satu uji coba terkontrol secara acak (randomized controlled trial, RCT) irama sinus berhasil dipertahankan selama 16 bulan pada $65 \%$ pasien yang diobati dengan amiodaron, dibandingkan dengan pasien yang diobati dengan sotalol atau propafenon yaitu sebesar 37\% (ARR 28\%, NNT 3.6). Namun studi terbaru menunjukkan bahwa upaya agresif untuk mempertahankan irama sinus dengan amiodaron atau obat lain tidak meningkatkan hasil pada pasien dengan gejala asimtomatik. Oleh karena itu terapi amiodaron jangka panjang dengan potensi toksisitas tidak dibenarkan bila diberikan pada pasien bersama obat antikoagulan jika dengan strategi kontrol saja dapat memberikan perbaikan yang gejala memuaskan. ${ }^{4,5}$

\section{Pengobatan akut}

Amiodaron intravena efektif untuk pengobatan darurat takiaritmia ventrikel. Efek antiaritmia amiodaron intravena terjadi dalam onset kurang dari 30 menit. Pedoman Advanced Cardiac Life Support (ACLS, tahun 2000) menyebutkan bahwa amiodaron dan procainamid dianjurkan sebagai pengobatan awal pada wide complex tachycardia dengan hemodinamik stabil. Namun penggunaan amiodaron pada pedoman ini hanya "mungkin efektif” pada refrakter ventricular tachycardia (VT) atau ventricular fibrillation (VF) tanpa nadi. Namun sebuah studi yang membandingkan penggunaan amiodaron dengan lidokain pada pasien rawat jalan VF menunjukkan bahwa terapi amiodaron secara substansial memperbaiki angka tahan hidup dan frekuensi masuk rumah sakit. ${ }^{4}$ (Bukti A, RCT).

Dosis amiodaron pada ACLS ditunjukkan pada Tabel 1. ${ }^{4}$ Pasien yang memerlukan terapi jangka panjang dosis intravena harus beralih ke dosis oral. Pasien yang menerima amiodaron intravena (IV) selama $<1$ minggu harus diberikan dengan dosis amiodaron 800-1.600 mg oral/hari. ${ }^{2}$ Pasien yang menerima amiodaron (IV) selama 1-3 minggu harus diberikan dosis 600-

$800 \mathrm{mg}$ oral/hari, dan pasien menerima amiodaron intravena untuk $>3$ minggu harus diberikan dosis $400 \mathrm{mg}$ per oral/ hari. ${ }^{4}$

\section{Kontraindikasi Amiodaron}

\section{Kontraindikasi amiodaron adalah : ${ }^{3}$}

- Disfungsi sinus yang berat dengan bradikardia atau sinkop

- Blok jantung derajat 2 atau 3

- Hipersensitif terhadap amiodaron

- Syok kardiogenik

\section{Efek Samping}

Amiodaron telah dikaitkan dengan toksisitas yang melibatkan organ paru, kelenjar tiroid, hati, mata, kulit, dan saraf yang ditunjukkan pada tabel 2.4

Toksisitas paru merupakan efek samping paling serius yang ditimbulkan oleh amiodaron. Frekuensi efek samping dihubungkan dengan pajanan amiodaron 
Tabel 1. Pedoman dosis Amiodaron (Cordaron)

\begin{tabular}{|c|c|c|c|}
\hline Indikasi & Administrasi & Dosis & Efek samping \\
\hline $\begin{array}{l}\text { Life- } \\
\text { threatening arrhythmia }\end{array}$ & IV & $\begin{array}{l}150 \mathrm{mg} \text { IV bolus selama } 10 \text { menit (jika perlu bolus } \\
\text { dapat diulang dalam } 10-30 \text { menit); kemudian } 1 \mathrm{mg} / \\
\text { mnt dalam } 6 \text { jam; kemudian } 0.5 \mathrm{mg} / \mathrm{mnt} \text { dalam } 18 \\
\text { jam; kemudian turunkan dosis IV atau ganti ke dosis oral } \\
\text { jika memungkinkan. }\end{array}$ & $\begin{array}{l}\text { Hipotensi, bradikardia, atrioventricular } \\
\text { block }\end{array}$ \\
\hline Ventricular arrhythmia & Oral & $\begin{array}{l}800-1600 \mathrm{mg} / \text { hari dalam dosis terbagi sampai dosis total } \\
10 \mathrm{~g} \text {; kemudian diberikan } 200-400 \mathrm{mg} / \text { hari. }\end{array}$ & $\begin{array}{l}\text { Bradikardia,pemanjangan interval QT, } \\
\text { gangguan GI, konstipasi; jarang } \\
\text { torsades de pointes }\end{array}$ \\
\hline Atrial fibrillation & Oral & $\begin{array}{l}600-800 \mathrm{mg} / \text { hari dalam dosis terbagi sampai dosis total } \\
10 \mathrm{~g} \text { (dapat diberikan dosis inisial yang tinggi atau IV); } \\
\text { kemudian } 200 \mathrm{mg} \text { per/hari }\end{array}$ & $\begin{array}{l}\text { Bradikardia, pemanjangan interval } \\
\text { QT,gangguan GI, konstipasi;jarang } \\
\text { torsades de pointes }\end{array}$ \\
\hline
\end{tabular}

$\mathrm{IV}=$ intravena; $\mathrm{GI}=$ gastrointestinal.

Dikutip dari (4)

Tabel 2. Efek samping Amiodaron (Cordaron)

\begin{tabular}{|c|c|c|c|}
\hline Efek samping & Frekuensi (\%) & Metode diagnosis & Tatalaksana \\
\hline \multicolumn{4}{|l|}{ Efek serius } \\
\hline $\begin{array}{l}\text { Toksisitas } \\
\text { Pulmonar }\end{array}$ & $2-17$ & $\begin{array}{l}\text { Foto toraks; uji faal paru, } \\
\text { termasuk DLco }\end{array}$ & Hentikan amiodaron; terapi inisiasi kortikosteroid. \\
\hline Hipertiroidisme & 2 & Kadar T4 bebas, kadar TSH & $\begin{array}{l}\text { Terapi inisiasi antitiroid; pertimbangkan } \\
\text { hentikan amiodaron. }\end{array}$ \\
\hline Hipotiroidisme & 6 & Kadar T4 bebas, kadar TSH & Berikan suplementasi hormon tiroid. \\
\hline Toksisitas hati & 1 & Enzim hati $3 \mathrm{x}>$ normal & Pertimbangkan hentikan amiodaron. \\
\hline Neuropati Optik & Tidak diketahui & Pemeriksaan mata & $\begin{array}{l}\text { Pertimbangkan hentikan amiodaron; } \\
\text { penyebab masih belum jelas. }\end{array}$ \\
\hline Proaritmia & $<1$ & EKG & hentikan amiodaron. \\
\hline Bradikardia & $2-4$ & PF, EKG & Jika berat, hentikan amiodaron atau pasang pacu jantung. \\
\hline \multicolumn{4}{|l|}{ Efek minor } \\
\hline Mual, anoreksia & 30 & Riwayat, (PF) & Turunkan dosis. \\
\hline $\begin{array}{l}\text { Mikrodeposit } \\
\text { kornea }\end{array}$ & $>90$ & Pemeriksaan dengan Slitlamp & Tidak ada \\
\hline Fotosensitif & $4-9$ & Riwayat, PF & Gunakan sunblock. \\
\hline Kulit kebiruan & $<9$ & $\mathrm{PF}$ & turunkan dosis. \\
\hline
\end{tabular}

total (dosis dan durasi pengobatan). Oleh karena itu amiodaron harus digunakan dengan dosis serendah mungkin dan menghentikan pengobatan bila efek samping terjadi. Mengenai hal tersebut akan dibahas dibawah ini.

\section{Faktor Risiko Toksisitas Paru Akibat Amiodaron}

Potensi faktor risiko untuk TPA adalah dosis kumulatif yang tinggi, dosis harian lebih besar dari 
$400 \mathrm{mg} /$ hari, durasi terapi $>2$ bulan $(400 \mathrm{mg}$ ), dosis rendah (200 mg sehari) selama lebih dari dua tahun. ${ }^{5}$ Laki-laki, usia lanjut, penyakit paru yang sudah ada sebelumnya atau foto toraks yang tidak normal sebelum dimulainya pengobatan amiodaron dan operasi bedah toraks atau angiografi paru dengan pemberian amiodaron memiliki peningkatan risiko untuk TPA. ${ }^{3,10-11}$

Kejadian awal TPA yaitu pada pasien yang biasa mengonsumsi $400 \mathrm{mg}$ atau lebih per hari dilaporkan 2\% sampai $17 \% .{ }^{4}$ Bahkan pada dosis yang paling umum digunakan oleh ahli jantung (200 mg/hari), Ott dkk melaporkan delapan kasus TPA. ${ }^{12}$ Studi Polkey dkk. menekankan, mungkin tidak ada dosis 'aman' untuk obat ini dan komplikasinya terus dilaporkan. ${ }^{13}$ Para penulis ini menekankan perlunya kewaspadaan bahkan dengan terapi amiodaron 'dosis rendah'. ${ }^{13}$

Menariknya mungkin ada perbedaan etnis atau ras dalam kerentanan untuk TPA. Studi Yamada dkk pada populasi Jepang menemukan kejadian kumulatif relatif tinggi untuk 1 tahun $(4,2 \%), 3$ tahun $(7,8 \%)$ dan 5 tahun (10,6\%), meskipun dosis pemeliharaan rata-rata hanya $141 \mathrm{mg} /$ hari. $^{14}$ Terbukti pula bahwa pajanan $\mathrm{O}_{2}$ tambahan dengan konsentrasi tinggi, sendiri atau bila dikombinasikan dengan ventilasi mekanis dapat berpotensi TPA. ${ }^{15,16}$ Oleh karena itu pasien yang menjalani operasi bedah toraks dan menerima amiodaron sangat rentan karena kemungkinan diperlukannya ventilasi mekanis pasca operasi. ${ }^{13,16}$

Studi Dusman RE dkk meneliti mengenai insiden dan prediktor klinis toksisitas paru amiodaron yang diperiksa pada 573 pasien dengan takiaritmia ventrikel berulang (456 pasien) atau supraventrikular (117 pasien). Toksisitas paru amiodaron didapatkan pada 33 dari 573 pasien $(5,8 \%)$, berdasarkan gejala dan kelainan foto toraks baru (32 dari 33 pasien) didukung dengan biopsi paru yang abnormal (13 dari 14 pasien), kapasitas difusi paru yang rendah (DLCO) (9 dari

13 pasien) dan / atau gallium scan yang abnormal (11 dari 16 pasien). Toksisitas terjadi antara 6 hari dan 60 bulan pengobatan dengan risiko kumulatif sebesar 9,1\%. Insiden tertinggi terjadi dalam 12 bulan pertama (18 dari 33 pasien). Pasien dengan usia tua lebih sering didapatkan TPA $(62,7+/-1,7$ vs $57,4+/-0,5$ tahun, $\mathrm{p}=0,018)$ dan tidak ditemukan kasus pada pasien yang memulai terapi kurang dari usia 40 tahun. Jenis kelamin, penyakit jantung yang mendasari, aritmia, kelainan foto toraks sebelum terapi, spirometri, atau volume paru yang abnormal tidak dapat memprediksi terjadinya TPA. Pemeriksaan DLCO yang lebih rendah sebelum terapi $(76,0+/$ $5,5 \%$ dibandingkan $90,4+/-1,4 \%, p=0,01)$ dapat memprediksi TPA. Pasien yang mendapatkan dosis pemeliharaan harian yang lebih tinggi signifikan untuk terjadinya TPA $(517+/-25$ vs $409+/-6 \mathrm{mg}$, p $<0,001)$, tetapi tidak ada perbedaan pada loading dose. Tidak terdapat TPA pada pasien yang menerima dosis pemeliharaan rata-rata harian $<305 \mathrm{mg}$. Pasien TPA juga ditemukan memiliki plasma desethylamiodarone lebih tinggi $(2,34+/-0,18$ vs $1,92+/-0,04 \mu \mathrm{g} / \mathrm{ml}$, p $=0,009){ }^{9}$ namun tidak untuk konsentrasi amiodaron selama terapi pemeliharaan. ${ }^{10}$

\section{Patogenesis Toksisitas Paru Akibat Amiodaron}

Sampai saat ini patogenesis terjadinya TPA belum diketahui sepenuhnya. Secara garis besar diketahui bahwa kerusakan paru akibat amiodaron dan metabolitnya dapat melalui mekanisme langsung (akibat efek sitotoksik) dan tidak langsung (akibat reaksi imunologis). ${ }^{9,1}$

Reaksi imunologis didukung dengan ditemukannya sel $T$ sitotoksik dalam cairan bronchoalveolar lavage (BAL) pada pasien yang didiagnosis TPA. 9,11,12 Amiodaron dapat menyebabkan produksi radikal $\mathrm{O}_{2}$ toksik, yang secara langsung dapat merusak sel-sel. ${ }^{9}$ Hal ini menyebabkan akumulasi fosfolipid dalam jaringan. $^{7-9}$

\section{Toksisitas paru secara langsung}

Amiodaron pada penelitian uji coba ternyata dapat berpengaruh secara langsung pada sel endotel paru yang dikultur dan menyebabkan inklusi lamelar. Akumulasi fosfolipid timbul dalam beberapa jam setelah sel terpajan obat dengan konsentrasi yang setara dengan dosis terapi. Saat konsentrasi amiodaron mencapai lebih dari $10 \mu /$ $\mathrm{ml}$ (setara dengan konsentrasi pada jaringan paru yang mengalami toksisitas), obat tersebut dapat menyebabkan cedera pada sel secara langsung dan menyebabkan kematian sel. Studi in vitro tersebut mendukung hipotesis behwa amiodaron dapat menyebabkan toksisitas dengan mempengaruhi sel secara langsung. Namun akumulasi fosfolipid juga dapat terjadi pada konsentrasi terapeutik sehingga penemuan akumulasi fosfolipid tidak selalu berarti toksisitas. ${ }^{8,9}$ 


\section{Mekanisme fosfolipidosis}

Mekanisme terjadinya akumulasi fosfolipid pada TPA akibat penghambatan pemecahan fosfolipid diantara sel-sel. Percobaan secara in vivo pada hewan maupun in vitro pada kultur sel ditemukan bahwa akumulasi fosfolipid setelah pengobatan dengan amiodaron terjadi karena amiodaron merupakan suatu inhibitor fosfolipase A yang sangat poten. Inhibisi terhadap aktivitas fosfolipase A ternyata juga sama efeknya terhadap fosfolipase A1 dan A2 yang cukup selektif untuk fosfolipase lisosomal dibanding fosfolipase mikrosomal. Efek inhibisi enzim lisosomal yang bertanggung jawab untuk katabolisme fosfolipid dapat diprediksi dengan didapatkannya peningkatan kandungan fosfolipid sel. ${ }^{8,9}$

Beberapa studi menunjukkan beberapa fosfolipid tertentu meningkat dengan konsentrasi yang relatif lebih tinggi dibanding dengan jenis fosfolipid lainnya setelah terpajan dengan obat- obatan yang bersifat Cationic Amphipilic Drug (CAD) seperti amiodaron. Sebagai contoh pada bismonoacylglycerol phosphate (BMAGP) telah dilaporkan kadarnya meningkat baik secara absolut maupun relatif dibanding dengan jenis fosfolipid lainnya yaitu fosfolipidosis yang dicetuskan oleh CAD. Demikian pula BMAGP meningkat pada sel paru manusia yang mengalami TPA sama seperti kultur sel endotel yang diinkubasi secara langsung dengan amiodaron. Ada kemungkinan besar bahwa BMAGP atau jenis fosfolipid lainnya dapat digunakan sebagai petunjuk efek samping amiodaron dalam bentuk metabolisme fosfolipid pada paru. ${ }^{8,9}$

Studi secara in vitro juga mengindikasikan kemampuan amiodaron untuk menjadi zat toksik secara langsung pada sel paru. Mekanisme cedera pada kejadian ini masih belum jelas. Beberapa kemungkinan adalah akibat akumulasi fosfolipid secara langsung menyebabkan cedera, kemampuan amiodaron yang dapat menimbulkan $\mathrm{O}_{2}$ toksik, kadar iodide pada molekul amiodaron yang berperan sebagai media terjadinya cedera dan sifat ampifilik amiodaron yang mengakibatkan obat ini dapat mempengaruhi sel atau fungsi membran organel. 8,9

Mekanisme lain yang menyatakan amiodaron menimbulkan cedera secara langsung yaitu terdapatnya iodide pada cincin benzene amiodaron. Telah diketahui amiodaron menyebabkan perubahan fungsi tiroid karena kemiripan amiodaron dengan hormon tiroid yang juga mengandung iodida. Iodida pada molekul amiodaron ini juga penting dalam menimbulkan toksisitas paru. ${ }^{8,9}$

Selain itu sifat amiodaron yang ampifilik menyebabkan amiodaron cenderung berkonsentrasi dalam jaringan banyak lemak karena struktur molekulnya. Amiodaron memiliki potensi untuk berinteraksi dan berumpul di antara lapisan fosfolipid pada sel atau membran organel. Gangguan pada membran sel ini dapat mempengaruhi fungsi sel secara keseluruhan. Masih diperlukan studi lebih lanjut mengapa sifat amiodaron tersebut hanya mempengaruhi organ tertentu. ${ }^{8,9}$

\section{Toksisitas paru akibat amiodaron secara tidak langsung}

Meskipun amiodaron berpotensi untuk menyebabkan TPA secara langsung, beberapa data dan pendapat bertentangan dengan mekanisme penyebab toksisitas tersebut. Terdapat hubungan yang tidak signifikan antara dosis harian amiodaron atau kadarnya dalam darah dengan timbulnya toksisitas paru. Studi awal menunjukkan beberapa petanda peningkatan reaksi imunologis pada pasien TPA. Data dari beberapa pasien TPA terdapat sel $\mathrm{T}$ supresor /sitotoksik $\left(\mathrm{CD}^{+}\right)$limfositosis yang didapat dari BAL yang sesuai reaksi hipersensitif pneumonitis. Namun mekanisme respon imunologis pada TPA tersebut belum dapat dimengerti sepenuhnya.,

Bukti yang mendukung timbulnya reaksi hipersensitif didapatkan dari BAL pasien TPA yaitu terdapatnya peningkatan kadar limfosit $\mathrm{CD} 8^{+}$dengan atau tanpa influks leukosit PMN. Hal ini menunjukkan bahwa penemuan limfositosis $\mathrm{CD} 8^{+}$merupakan alat diagnostik yang penting untuk mendukung diagnosis TPA. Banyak faktor yang belum diketahui dalam hubungan $\mathrm{CD}^{+}$limfositosis dengan TPA. Contoh studi imunokemikal pada jaringan paru pasien dengan TPA belum dapat menjawab apakah limfosit $\mathrm{CD}^{+}$ada di interstisial dan juga belum jelas peran makrofag alveolar dalam respon imun yang mendasari kelainan toksisitas tersebut. ${ }^{8,9}$ Mekanisme patogenesis TPA dapat dilihat pada gambar 2 .

\section{Gambaran Patologi Toksisitas Paru Akibat Amiodaron}

Pemeriksaan mikroskopis jaringan paru pasien TPA didapatkan gambaran pneumonitis interstitial difus. $\mathrm{Hal}$ ini ditunjukkan dengan gambar 3A. Didapatkan 


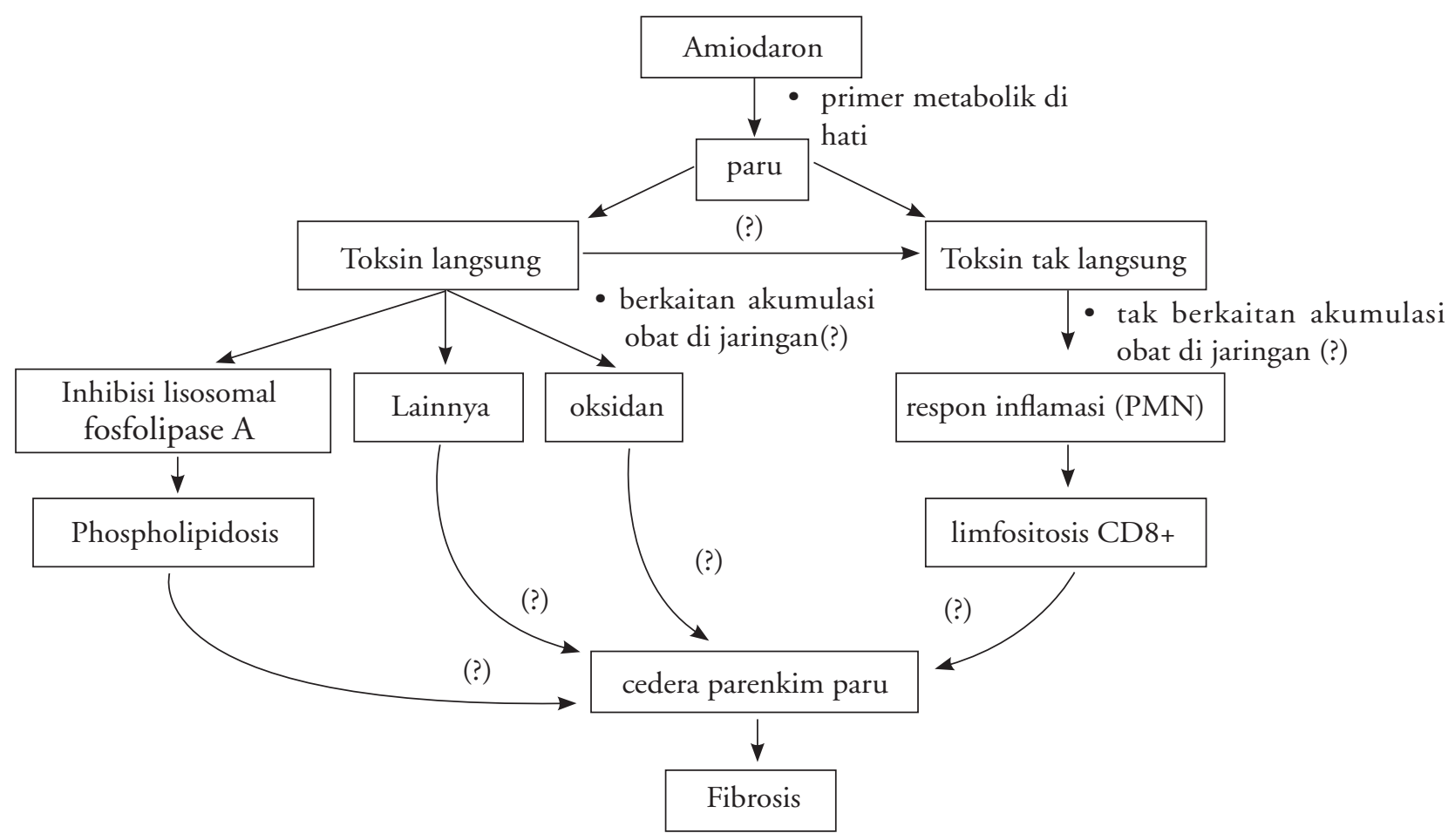

Gambar 2. Mekanisme patogenesis toksisitas paru akibat amiodaron Dikutip dari (9)
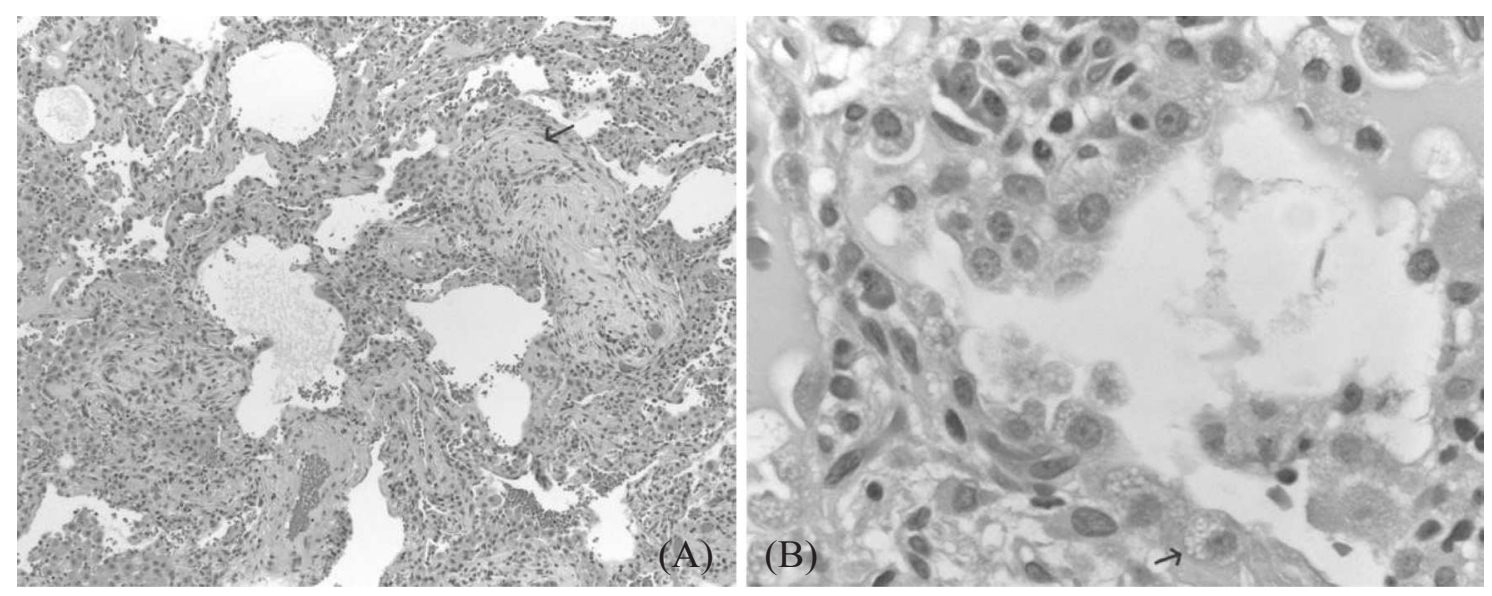

Gambar 3. A. Parenkim paru menunjukkan inflamasi interstisial dan penebalan jaringan fibroblastik dalam lumen saluran napas pada pneumonia (panah). B. Alveolus menunjukkan inflamasi interstisial dan hiperplasia pneumosit tipe II. Pneumosit menunjukkan banyak vakuola sitoplasma yang kasar (panah). Dikutip dari (5) 
gambaran hiperplasia pneumosit tipe II dan pelebaran septa alveolar dan inflamasi selular dengan fibrosis interstisial. Vakuola sitoplasma terlihat pada pneumosit alveolar, sel-sel epitel bronkial dan sel endoteldengan mikroskop cahaya. ${ }^{5,17} \mathrm{Hal}$ ini ditunjukkan pada gambar 3B. Karakteristik yang khas adalah dengan ditemukannya akumulasi lipid (makrofag berbusa) dalam ruang alveolar. Makrofag berbusa dengan badan inklusi lamelar dilaporkan juga bukan hanya terdapat pada pasien TPA kronik. ${ }^{5}$ Myers dkk menyimpulkan bahwa untuk sementara makrofag alveolar berbusa dan badan lamelar sitoplasma tidak spesifik untuk karakteristik TPA dan kehadirannya sendiri saja tidak dapat membedakan pasien TPA dengan toksisitas obat lainnya. ${ }^{18}$

\section{Temuan Klinis}

Temuan klinis yang paling sering ditemukan pada TPA adalah pneumonitis alveolar/interstisial pada onset subakut. Pasien biasanya telah mendapatkan amiodaron selama berbulan- bulan atau bahkan beberapa tahun. Pasien biasanya datang dengan keluhan sesak napas progresif (71\%), batuk nonproduktif $(25 \%)$, demam $(21 \%)$, nausea $(7 \%)$, fatigue $(7 \%)$, nyeri dada pleuritik (4\%), dan penurunan berat badan (4\%). Pemeriksaan fisis untuk kasus ringan bisa tanpa kelainan, namun pada keadaan yang lebih berat dapat ditemukan rhonki yang difus, hipoksemia dan distress pernapasan. $8,10,13$

\section{Gambaran Laboratorium}

Secara laboratorium jarang ditemukan leukositosis dibandingkan eosinofilia. 5 Sering terdapat elevasi non spesifik pada laktat dehidrogenase, serum KL-6 atau glikoprotein, namun hal ini tidak dapat membedakan TPA dengan penyakit paru interstitial lainnya. Pemeriksaan serum KL-6 positif bila lebih dari 500 $\mathrm{U} / \mathrm{ml}$ (sensitivitas $8 \%$ dan spesifisitas $91 \%$ ).

\section{Uji Faal Paru}

Uji faal paru biasanya menghasilkan penurunan volume dan restriktif paru. Penurunan DL $\mathrm{DO}_{\mathrm{C}}$ merupakan khas namun tidak spesifik. Penurunan DLco $>20 \%$ memberikan sensitivitas $84 \%$ dan

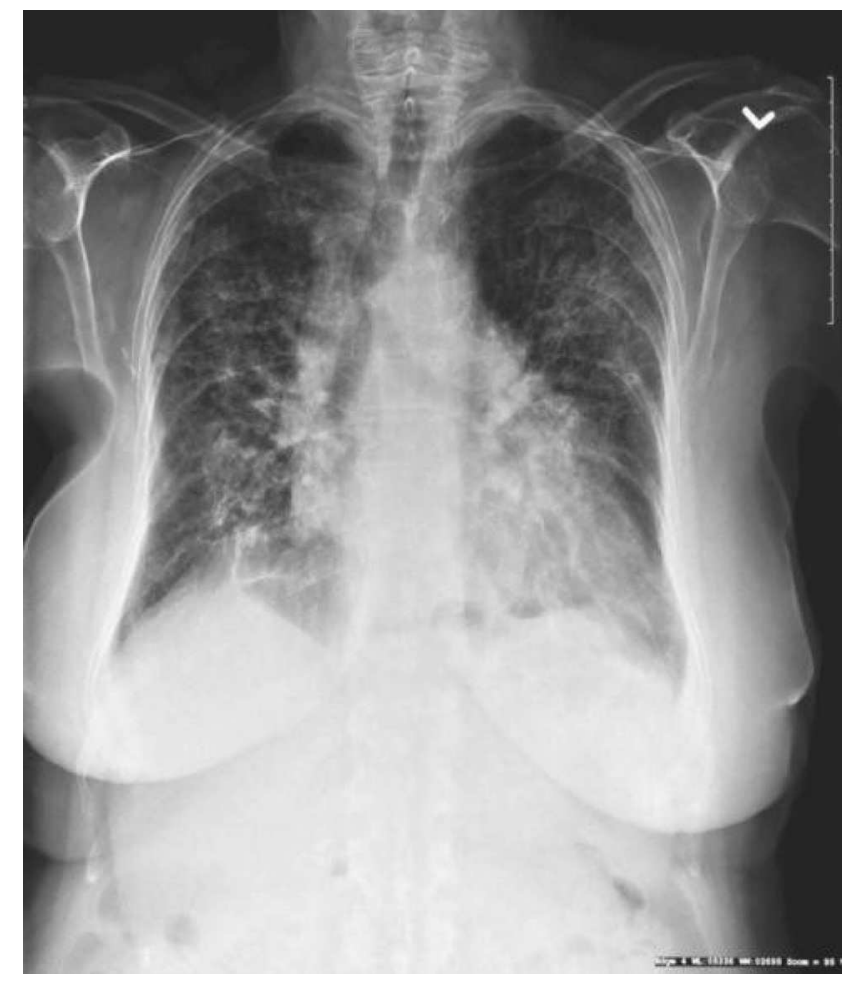

Gambar 4. Foto toraks postero-anterior seorang perempuan 79 tahun dengan TPA. Terdapat gambaran berupa infiltrat bilateral dan infiltrat interstisial. Dikutip dari (5)

spesifisitas 73\%. Kondisi hipoksemia dapat diukur dengan pulse oximetry sederhana atau dengan analisis gas darah arteri. ${ }^{14}$

\section{Gambaran Radiologis}

Radiologi memainkan peran penting untuk mendiagnosis. Foto toraks menunjukkan gambaran infiltrat merata atau difus yang umumnya bilateral. Hal ini ditunjukkan Gambar 4. Infiltrat memiliki penampilan 'ground glass'. Lokasi biasanya pada paru kanan terutama lobus atas lebih sering terkena dibanding paru kiri. ${ }^{5,17}$ Pemeriksaan High Resolution Computed Tomography (HRCT) sering menggambarkan kelainan yang lebih luas daripada foto toraks yang umumnya terdapat gambaran interstisial bilateral, alveolar atau interstisial campuran dan infitrat alveolar. ${ }^{5} \mathrm{Hal}$ ini ditunjukkan gambar 5 .

Infiltrat di parenkim yang memiliki penyangatan tinggi merupakan gambaran khas dan diyakini berhubungan dengan sifat iodinasi obat dan waktu 

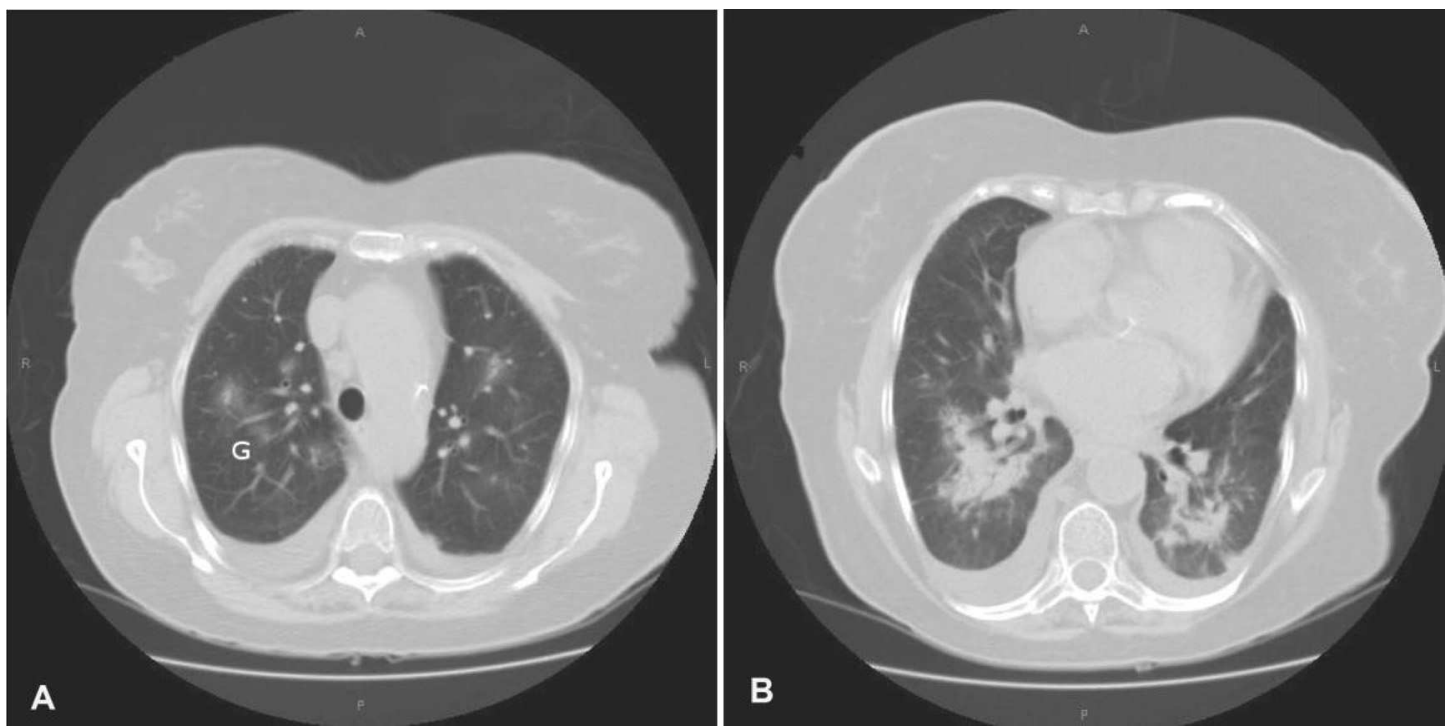

Gambar 5. Merupakan gambaran CT scan pada pasien yang sama. A. Potongan gambar lobus atas menunjukkan infiltrat bilateral dengan ground glass opacity pada beberapa area (G). B. Potongan CT scan lobus bawah menunjukkan infiltrat basilar bilateral dan efusi pleura minimal.

Dikutip dari (19)

paruh yang panjang di paru. ${ }^{19}$ Ground glass opacity lebih mudah dan sering terlihat pada HRCT daripada foto toraks. ${ }^{20}$ Gambarannya sering berdistribusi secara perifer dan mungkin merupakan temuan awal TPA. Oyama dkk berspekulasi bahwa temuan awal TPA berupa ground glass opacity merupakan petunjuk untuk mendeteksi komplikasi ini pada tahap awal dan berpotensi reversibel. Penebalan pleura terutama terlihat pada daerah infiltrat terpadat. ${ }^{20}$ Efusi pleura jarang ditemukan. ${ }^{5}$ Penyangatan tinggi pada hati dan limpa sering didapatkan secara kebetulan pada HRCT akibat akumulasi amiodaron dan metabolitnya di makrofag jaringan. Namun ditemukannya metabolit dalam makrofag meskipun diduga dari pajanan amiodaron tidak selalu berhubungan dengan TPA. Temuan HRCT pada TPA dirangkum dalam Tabel 3. ${ }^{19}$

Gallium scanning pada beberapa kasus dapat menunjukkan peningkatan aktivitas parenkim terutama pada keadaan dini atau ringan. Kelainan pada gallium scanning dapat berkorelasi sesuai derajat beratnya TPA dan bisa membantu membedakan infiltrat akibat gagal jantung kongestif. ${ }^{21}$ Namun

Tabel 3. Temuan HRCT pada toksisitas paru akibat amiodaron (TPA)

\begin{tabular}{lll}
\hline Organ & \multicolumn{1}{c}{ Temuan } & Keterangan \\
\hline Parenkim paru & $\begin{array}{l}\text { Ground glass opacity } \\
\text { Infiltrat interstisial, alveolar atau campuran Penyangatan } \\
\text { tinggi pada area infiltrat Nodul paru atau 'massa' } \\
\text { Densitas basal reticular opacitiy; traksi bronkiektasis }\end{array}$ & $\begin{array}{l}\text { Lokasi perifer; bisa pada kondisi dini } \\
\text { Biasanya bilateral }\end{array}$ \\
& & Akibat amiodaron kaya iodine Dapat tunggal \\
& & atau multipel; sering pada lokasi perifer \\
Abdomen & Penyangatan tinggi pada hati dan limpa & Diduga fibrosis pulmonar \\
& & Amiodaron dan metabolitnya pada makrofag \\
Pleura & Penebalan pleural & jaringan \\
& Efusi pleural & Umum \\
\hline
\end{tabular}

Dikutip dari (19) 
demikian temuan gallium scanning tidak spesifik, relatif mahal dan memerlukan waktu 48 sampai 72 jam. Biopsi paru terbuka sering terdapat obliterans bronkiolitis dengan pneumonia. Hal ini sering dipandang sebagai pneumonitis intertisial difus. ${ }^{5,13}$

Gambaran radiografi yang jarang pada TPA yaitu ditemukannya nodul paru tunggal atau ganda dan dapat berupa massa opacity. Kelainannya sering terlihat di lobus atas, lokasi sering di perifer dan mungkin berbatasan pleura. ${ }^{5,22}$ Terdapatnya nodul dapat disebabkan akumulasi lokal akibat obat dari peradangan sebelumnya. ${ }^{5}$ Biasanya didapatkan penyangatan yang tinggi akibat amiodaron yang kaya yodium pada lesi pneumosit tipe II. ${ }^{22}$ Penting untuk diketahui apakah nodul/massa mengalami peningkatan ambilan fluorodeoxyglucose pada Positron Emission Tomography (PET) scanning, yang merupakan positif palsu pada neoplasma paru.

Manifestasi paling berat dari TPA adalah kondisi yang progresif cepat dan difus pada pneumonitis dengan gagal napas akut dan sindrom distres pernapasan akut. Hal ini dapat diketahui dengan pemberian kontras saat angiografi pada pasien yang menjalani operasi jantung atau paru terutama pneumonektomi. ${ }^{15}$ Van Meighen dkk melaporkan kejadian ARDS pasca operasi yaitu $11 \%$ pada pasien yang diobati dibandingkan dengan mereka yang tidak diobati amiodaron yaitu 1,8\%. ${ }^{23}$ Telah dilaporkan kejadian ARDS saat amiodaron digunakan sebagai profilaksis sebelum operasi atau pasca operasi untuk mengobati aritmia baru. ${ }^{23,24}$ Kerentanan terhadap TPA sangat meningkat terutama pada mereka yang menjalani operasi kardiotoraks dengan penyakit paru kronik dan membutuhkan $\mathrm{O}_{2}$ tambahan atau ventilasi mekanis selama periode perioperatif. Ashrafian dan Davey telah menyoroti kemungkinan amiodaron sebagai diagnosis yang terlewatkan pada penyebab gagal napas akut dalam unit perawatan intensif. ${ }^{15}$

Kemungkinan angka menjadi tinggi akibat TPA. Otopsi pada kasus ini selalu ditemukan kerusakan alveolar difus, pembentukan membran hialin, penebalan septum dan makrofag berbusa.

Fibrosis paru dapat terjadi pada 5\% sampai 7\% pasien yang mengalami pneumonitis amiodaron yang khas. ${ }^{5}$ Hal ini dapat tanpa gejala khas karena kemungkinan pada fase pneumonitis memiliki gejala subklinis dan sulit dikenali. Pasien biasanya didapatkan gejala sesak napas, hipoksemia dengan desaturasi dan kadang disertai penurunan berat badan. Ronkhi yang difus dapat didengar pada auskultasi. Foto toraks menunjukkan penyakit paru interstitial yang difus. Pemeriksaan HRCT menunjukan gambaran interstisial kasar, retikuler atau retikulonodular yang opak dan bronkiektasis. Sarang lebah jarang ditemukan dibandingkan fibrosis paru idiopatik. Manifestasi yang tidak biasa dari TPA adalah hemoragik alveolar yang berkaitan dengan hemoptisis. Komplikasi ini harus dimasukkan dalam diagnosis diferensial hemoptisis pada pasien yang mendapatkan amiodaron. ${ }^{5}$

\section{Diagnosis}

Sampai saat ini belum ada uji laboratorium atau pemeriksaan klinis yang sahih untuk dapat menegakkan diagnosis TPA. Untuk membuat diagnosis TPA secara klinis diperlukan metoda eksklusi kemungkinan diagnostik lainnya terutama gagal jantung kongestif bersamaan dengan dikumpulkannya penemuan atau gejala yang konsisten dengan diagnosis TPA. ${ }^{5}$

Kudenchuk dkk mendefinisikan TPA jika ditemukan paling sedikit dua kriteria di bawah ini: ${ }^{7}$

1. Timbulnya gejala baru yang mengalami perburukkan

2. Terdapatnya kelainan yang baru atau perburukan pada foto toraks penderita

3. Penurunan paling sedikit $15 \%$ dari kapasitas paru total.

Beberapa kriteria tambahan yang perlu dipertimbangkan untuk menegakkan diagnosis TPA:

1. Tidak ditemukan fosfolipidosis mengurangi kemungkinan diagnosis TPA

2. Ditemukan limfositosis pada pemeriksaan BAL sangat mendukung TPA

3. Biopsi paru menunjukkan kerusakan alveolar yang difus, pneumonitis interstisial atau gambaran fibrosis yang konsisten dengan TPA

4. Penghentian amiodaron dengan atau tanpa pemberian steroid akan mengurangi bahkan menghilangkan gejala.

Dusman MD dkk juga menambahkan kriteria diagnosis untuk TPA yaitu bila terdapat penurunan nilai DLco sebelum dimulai pengobatan (20\%) atau $<80 \%$ dari nilai prediksi dan bila didapatkan nilai 
abnormal pada radioisotop gallium- $67 .{ }^{10}$

Setiap pasien yang mendapatkan amiodaron dengan gejala baru atau terdapatnya perburukan dan /atau infiltrat baru pada foto toraks patut dicurigai sebagai TPA. Pasien yang rentan mungkin beresiko terjadinya edema paru, pneumonia, emboli paru akut atau lainnya yang dapat membuat kesulitan diagnosis. Diagnosis penunjang yang tepat seperti foto toraks dan CT scan dapat mendukung diagnosis untuk segera memulai pengobatan. Pemeriksaan tambahan dapat dilakukan bila diperlukan. Uji faal paru biasanya menunjukkan restriktif atau campuran antara obstruktif dengan restriktif. Kapasitas difusi paru biasanya menurun. Toksisitas amiodaron yang signifikan tampaknya tidak mungkin terjadi bila tidak didapatkan penurunan DLCO minimal sebesar $15 \%$ sampai $20 \%$. Bila hanya terdapat penurunan $\mathrm{DL}_{\mathrm{CO}}$ tanpa bukti klinis tidak dapat diagnosis sebagai TPA. ${ }^{24}$

Bronkoskopi serat optik dengan BAL dan transbronkhial biopsi dapat sangat berguna terutama untuk menyingkirkan penyebab lain penyakit paru difus. Bronchoalveolar lavage (BAL) dapat menjadi bukti terjadinya respon inflamasi atau imunitas. 7,8 Sering terdapat peningkatan leukosit PMN dan set $\mathrm{T}$ supresor $\mathrm{CD}^{+}$. Terdapatnya makrofag 'berbusa' konsisten dengan diagnosis, namun sel-sel ini juga dapat dilihat pada satu sampai setengah pada pasien nontoksik yang menerima amiodaron. ${ }^{8}$ Bila tidak terdapat sel busa diagnosis dapat dianggap bukan TPA. ${ }^{10,11}$ Beberapa kasus bila diagnosis tidak jelas, mungkin diperlukan biposi paru terbuka. Namun hal ini harus dihindari bila terdapat kecenderungan terjadinya TPA yang memburuk pasca operasi toraks karena pasien biasanya memiliki gangguan fungsi jantung dan paru. ${ }^{8}$

\section{Tatalaksana Toksisitas Paru Akibat Amiodaron}

Obat harus dihentikan ketika diagnosis dianggap kemungkinan TPA. Resolusi amiodaron cenderung melambat ketika obat diberhentikan namun dapat terjadi perburukan beberapa derajat sebelum terjadinya perbaikan. Hal ini dikaitkan dengan eliminasi waktu paruh obat yang panjang dan kecenderungan konsentrasi pada jaringan seperti paru. Beberapa penulis telah mencatat bahwa semakin cepat timbulnya serangan berbahaya penyakit ini, semakin lambat untuk beresolusi. ${ }^{8}$
Kortikosteroid sistemik dianjurkan untuk pengobatan TPA meskipun uji coba terkontrol menunjukkan efikasi yang kurang. Prednison umumnya dimulai dengan dosis 40 sampai $60 \mathrm{mg}$ / hari secara oral dan dikurangi bertahap (tapering off) secara lambat. Farmakodinamika amiodaron menentukan pengobatan ini yang dapat mencapai 4 sampai 12 bulan. Telah dilaporkan kasus kambuh akibat penghentian steroid lebih awal. ${ }^{25}$ Okayasu dkk menyebutkan bahwa pasien dengan kelebihan jaringan adiposa (diukur dengan peningkatan indeks massa tubuh) lebih rentan terhadap kekambuhan pada tapering steroid karena tingginya konsentrasi amiodaron lipofilik dalam jaringan adiposa. ${ }^{25}$

Prognosis TPA umumnya makin baik bila terdiagnosis lebih awal. Perkembangan penyakit ke tingkat lebih lanjut dapat berakibat fatal atau menyebabkan fibrosis paru. Angka kematian tertinggi adalah bilamana penyakit ini berkembang menjadi ARDS. ${ }^{15}$

\section{Pemantauan Dan Pencegahan}

Pasien yang memulai terapi amiodaron harus diberitahu tentang potensi terjadinya efek samping dan ditekankan untuk segera melaporkan setiap timbul gejala gangguan pernapasan yang baru. Pasien harus memiliki pemeriksaan awal foto toraks dan uji fungsi paru termasuk DLCO. Hal ini berfungsi sebagai dasar referensi kemungkinan terjadinya toksisitas yang meragukan. Pedoman saat ini menyarankan bahwa pemeriksaan foto toraks per tahun diperlukan selama pasien mendapatkan pengobatan amiodaron. ${ }^{10}$ Foto toraks dan uji faal paru harus segera dilakukan jika ada kecurigaan klinis TPA. ${ }^{19}$ Goldschlager dkk baru-baru ini memperbarui pedoman angka tahan hidup (surveillance) untuk dokter yang merawat pasien amiodaron termasuk rekomendasi untuk memantau toksisitas paru. ${ }^{11} \mathrm{Hal}$ ini termasuk pemantauan uji fungsi tiroid, uji fungsi enzim hati, serta tindakan perlindungan bagi kulit yang fotosensitif. 1,4,10,11 Tidak direkomendasikan pemantauan rutin untuk memeriksa kadar plasma amiodaron (Bukti C berdasarkan konsensus).

Saat ini tidak ada langkah-langkah yang terbukti dapat mencegah TPA. Satu-satunya strategi yang tampaknya berkhasiat adalah dengan menggunakan dosis sekecil mungkin untuk setiap pasien tertentu. 
Vitamin E telah terbukti mengurangi tingkat kerusakan paru setelah pemberian amiodaron pada hewan eksperimental. Namun sampai sekarang belum terdapat penelitian klinis yang menunjukkan bahwa hal ini merupakan strategi pencegahan yang efektif untuk TPA. ${ }^{5}$

\section{Kesimpulan}

1. Efek samping amiodaron tetap harus diwaspadai seiring peningkatan penggunaan obat ini meskipun kejadian komplikasi amiodaron mengalami penurunan dengan digunakannya amiodaron dengan dosis yang lebih rendah.

2. Manifestasi klinis TPA dapat ringan, berat bahkan mengancam jiwa.

3. Kebanyakan pasien berespon baik dengan kortikosteroid saat efek samping TPA terjadi.

4. Pemeriksaan foto toraks dan faal paru sebaiknya dilakukan sebelum memulai terapi.

5. Semua pasien yang memakai amiodaron harus diikuti dan dipantau dengan hati-hati untuk memastikan diagnosis yang tepat saat toksisitas ini terjadi

\section{Daftar Pustaka}

1. Vassallo P, Trohman RG. Prescribing amiodaron. JAMA. 2007;298:1312-22.

2. Ernawati DF, Stafford L, Hughes FD. Amiodaron - Induced pulmonary toxicity. BR J Clin Pharmacol. 2008;66:82-7.

3. Zimetbaum P. Amiodaron for atrial fibrillation. N Engl J Med. 2007;356:935-41.

4. Siddoway L. Amiodaron: Guidelines for use and monitoring. Am Fam Physician. 2003;68:2189-96.

5. Wolkove N, Baltzan M. Amiodaron pulmonary toxicity. Can Respir J. 2009;16:43-8.

6. Roy D, Talajic m, Dorian P. Amiodarone to prevent recurrence of atrial fibrillation. Canadian Trial of Atrial Fibrillation Investigators. N Eng J Med. 2000;342:913-20.

7. Kudenchuk PJ, Pierson DJ, Green HL, Graham EL, Sears GK, Trobaugh GB. Prospective evaluation of amiodaron pulmonary toxicity. Chest 1984;86;541-8.

8. Martin WJ, Rosenow EC. Amiodaron pulmonary toxicity: Recognition and pathogenesis (Part 1) Chest. 1988;93:106775.

9. Martin WJ, Rosenow EC. Amiodaron pulmonary toxicity: Recognition and pathogenesis (Part 2) Chest. 1988;93:1242-8.
10. Dusman MD, Stanton MS, Miles WM, Klein LS, Zipes DP, Fineberg NS, et. al . Clinical features of amiodarone induced pulmonary toxicity. Circulation. 1990;82:51-9.

11. Goldschlager N, Epstein AE, Naccarelli GV, et al. A practical guide for clinicians who treat patients with Amiodaron: 2007. Heart Rhythm. 2007;4:1250-9.

12. Ott MC, Khoor A, Leventhal JP. Pulmonary toxicity in patients receiving low-dose Amiodaron. Chest. 2006;123:64651.

13. Polkey MI, Wilson PO, Rees PJ. Amiodaron pneumonitis: No safe dose. Respir Med. 1995;89:233-5.

14. Yamada Y, Shiga T, Matsuda N. Incidence and predictors of pulmonary toxicity in Japanese patients receiving low-dose amiodaron. Circ J. 2007;71:1610-6.

15. Ashrafian H, Davey P. Is Amiodaron an underrecognized cause of acute respiratory failure in the ICU. Chest. 2001;120:27582.

16. Saussine M, Colson P, Auauzen M. Post-operative acute respiratory distress syndrome: A complication of Amiodaron associated with 100 percent oxygen ventilation. Chest. 1992;102:980-1.

17. Malhotra A, Muse VV, Mark EJ. An 82 year old man with dyspnea and pulmonary abnormalities. Case records of the Massachusetts General Hospital. N Engl J Med. 2003;348:1574-85.

18. Myers JL, Kennedy JI, Plumb VJ. Amiodaron lung: Pathologic findings in clinically toxic patients. Hum Pathol. 1987;18:34954.

19. Kuhlman JE, Teigen C, Ren H. Amiodaron pulmonary toxicity: CT findings in symptomatic patients. Radiology. 1990;177:121-5.

20. Oyama N, Oyama N, Yokoshiki H. Detection of amiodaroninduced pulmonary toxicity in supine and prone positions: High resolution computed tomography study. Circ J. 2005;69:466-70.

21. Zhu YY, Botvinick E, Dae M. Gallium lung scintigraphy in amiodaron pulmonary toxicity. Chest. 1988;93:1126-31.

22. Azzam I, Tov N, Elias N. Amiodaron toxicity presenting as a pulmonary mass and peripheral neuropathy: The continuing diagnostic challenge. Postgrad Med J. 2006;82:73-5.

23. Van Mieghem W, Coolen L, Malysse I. Amiodaron and the development of ARDS after lung surgery. Chest. 1994;105:16425.

24. Handschin AE, Lardinois D, Schneiter D. Acute amiodaroninduced pulmonary toxicity following lung resection. Respiration. 2003;70:310-2.

25. Okayasu K, Takeda Y, Kojima J. Amiodaron pulmonary toxicity: A patient with three recurrences of pulmonary toxicity and consideration of the probable risk of relapse. Intern Med. 2006;45:1303-7. 